垁 29 巻(1976) $137-145$ 算

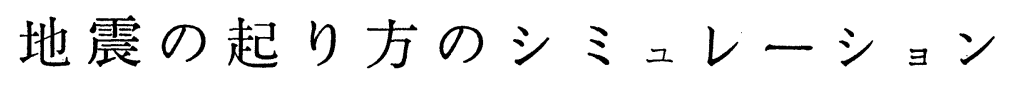

第五部 余震とは何か

熊本大学理学部物理学教室 大 塚 道 男

(昭和 51 年 5 月 14 日受理)

\title{
A Simulation of Earthquake Occurrence
}

Part 5 An Interpretation of Aftershock Phenomena

Michio OTSUKA

Department of Physics, Faculty of Science Kumamoto University

(Received May 14, 1976)

According to the chain-reaction type source model which the author has proposed throughout this series of paper, areas of variety of size in which seismic energy is still left unliberated are known to be dispersed within the source domain of the main shock. The assumption that these regions are cause of aftershock is shown to be successfully applied in explaining various aspects of the phenomena.

\section{§1. はじめに}

このシリーズを通じて，筆者は地震の震源での破壞の形式は，一点から始をる確率的連鎖反 応に似たものであろうことを主張して来た．筆者は，この過程を碁になぞらえて，碁石モデル と名付快（大塚，1971）が，後にこれが浸透モデルの一つのケースであることがあきらかに なつた（大塚，1975a）．従つて筆者の提案は，浸透モデルが地震学に応用できるといら主張で あつたわけである.

筆者がこのモデルの有用性を説いたのは，地震の大きさの分布についての規則性がこれで説 明できることに起因していたのであるが実際に震源でそのようなプロセスが起つているのな ら，他にもその証拠がなければならない。

本稿では余震という現象をとり上げ，その解釈に浸透モデルが有効に適用されることを示し たい。

余震は一般の地震活動との間を明瞭に劃する側面を幾つも備えている．例えば，余震は本震 の発生を境にして急に活動度を高めること. その震源は本震の断層の位置を暗示する部分に集 中して起ること, しかし, 時間が経過するに従い, その活動は一定規則に従つて衰微し, 同時 
に震源の位置も莫然となり, 遂には一般の地震活動に移行すること, 一般に大きい本震程強い 地震活動と大きな余震を伴なう傾向があり, 小さい地震では余震を伴なうことが少なくなるこ となどである。

こうした諸々の属性を備えた余震現象が，浸透モデルを導入することにより，統一的に解釈 できる可能性のあることを提案するのが本稿の目的である.

\section{§2. 浸透モデルにおける余震とは}

さて, Fig. 1 に伝播確率を 0.32 において得られた二次元正方格子における浸透図形の幾つ かを示す．地震学的な解釈をすれば，黒くぬりつぶした部分は歪ェネルギーがすでに解放され た所，白い部分は未開放部分である。これらの図形は乱数の決める所であつて一つ一つがすこ ぶる個性的である，筆者は，その多様性を地震波や被害状況の多様性に，またその大きさの分 布を地震の大きさの分布に対応づけることを主張して来たのであつた.
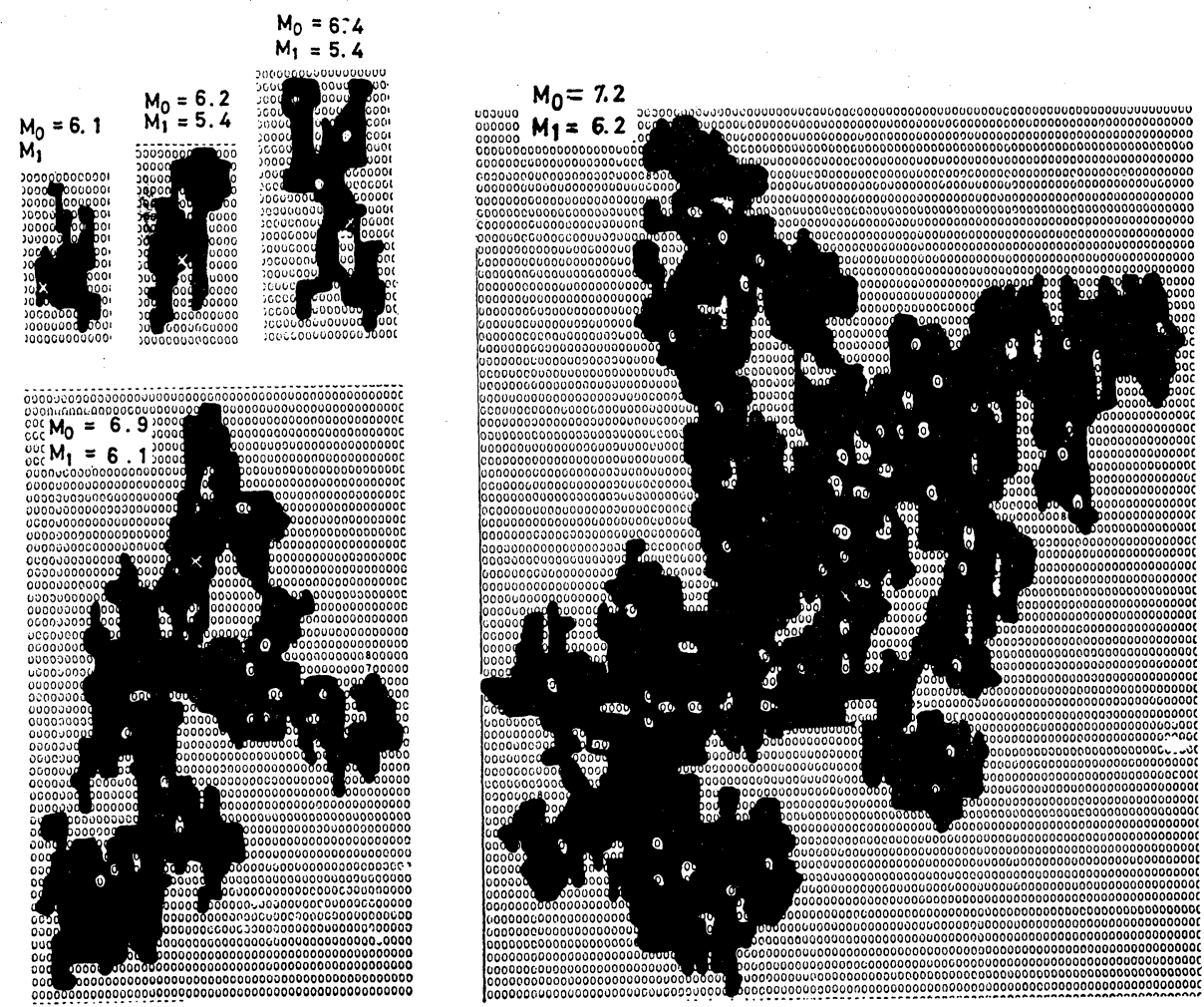

Fig. 1. Examples of focal domain expected from percolation model. Regions where seismic energy is left unreleased within the focal domain are assumed to be origins of aftershocks. 
ところで, Fig. 1 の各図形の中には，黒くぬつた部分の内部に点々と白い部分が残されて いることが認められる．黑い部分では，すでに歪エネルギーが開放された安定状態が実現して いるが，それに囲まれた未解放域は先端集中応力の作用に曝され，僅かなトリガーで安定状態 へ移行しやすい，いわばメタネテーブルな状態にあると思われる.

そこで，黒くぬつた部分のエネルギー開放といら事件を本震の発生と考光，空白部分が次々 と埋まつてゆく現象を余震現象と考えよう, というのが本稿の出発点である.

\section{§3． 余震の規模別頻度分布}

余震の観測結果を整理すると，そのマグニチュード別の出現頻度が，いわゆる GutenbergRichter の関係をみたすことが知られている，また，そのときに求まる $B$ の值が，一般の地 震活動に打けるそれよりも大きく求まり，一見異なる母集団からのサンプリングの様に見える といら報告も多い.

§2. に述べたような余震の考方方で，上の観測事実を説明できるであろらか。そこである一 つのクラスターに含まれる空白部の大きさを，筆者の常に用いる手段（大塚，1971）によつて マグニチュードに変換し，その頻度分布を作つたのが Fig. 2 の黒丸である. 黒丸の並び方 は，あきらかに Gutenberg-Richter の関係を想起させるものであることに注意してほしい. Fig. 2 の白丸は，主震を作るときに与えた伝播確率 $p=0.32$ に対応する頻度分布である. 云 わば主震系列の規模別頻度分布と思つてょい. 地震の頻度分布形式として, 白丸の並び方は適 当でないのであるが，これは均一な伝播確率 $p$ をもつ二次元格子浸透モデルに個有なもので (丸山：1975), その点一般の地震観測に経験する直線状分布を説明するためには伝播確率に 地域的なゆらぎがあることを想定すればよい ことが大塚 $(1975, b)$ によつて示されている. 従つて, ここで筆者の主張したいことは, 余 震が Gutenberg-Richter の関係をみたすこ と, その分布形式は本震系列のものと全く違 らことである.

浸透モデルに何故空白域が発生するのか. なぜ，その大きさが規則性を示すのか，等考 えなければならない問題が多く未解決である が，少なくとも大きさの分布に関して，浸透 モデルは都合のいい基盤を与えることは確か

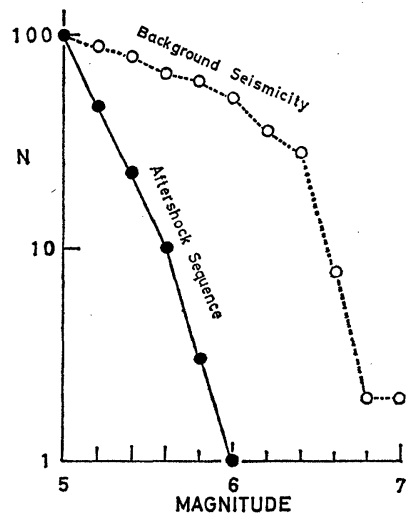

Fig. 2. Magnitude-frequency relation of the simulated aftershocks (solid circles) and of the mainshock series (open circles). 
である.

\section{§4． 本震の大きさと余震活動の強さ}

実際の余震活動において, 本震のマグニチュードは, それに伴なう余震活動にとつて, 決定 的な意味を持つことが多い. 一般的に本震が大きいほど余震活動が高く, 余震も大きいものが 期待される. また，小さい地震ほど余震を伴なわない可能性が大きくなる等である. Fig. 1 の例では浸透図形が小さいものから順に並べてあるが，それぞれの内部にある空白部に着目す るとき，元の図形が大きくなる程，独立した空白部の数が多く，最大の空白部の大きさも大き くなることを見ていただきたい，更に一番小さい図形にあつては，空白部は一つもなくなつて いることも注意してほしい。

さて. 前述のように図中黒い部分の面積 は，本震のマグニチュードに対応すると思わ れるのでこれを変換して $M_{0}$ とし, 一方最大 の空白部の面積は最大余震に当ると考え, こ れも同じ仕方でに変換する. Fig. 1 の各図 の上には，その值が書いてある。こういう操 作を数多くの図形について扣こない， $M_{0}$ 〜 $M_{1}$ のグラフにしたものを Fig. 3 の黒丸で 示す.

プロットの傾向をはつきりさせるために， 暗い蔭を施こした．Fig. 3 の白丸は UTSU (1961) によつてまとめられた実際の地震に ついてのプロットである. 実際の地震のデー タの方が遙かにバラッキの幅が大きく，その 上黒丸の位置が白丸の散らばりの中央に落ち ないことも不満足であるが，これはモデルに あつては恐らく実際には存在しない破壊の素 量といらものを考えていることと, 素量から マグニチュードへの変換の方法のまずさ等に 起因するものと思われる.

注目したいのは, 黒丸と白丸の右上りの傾

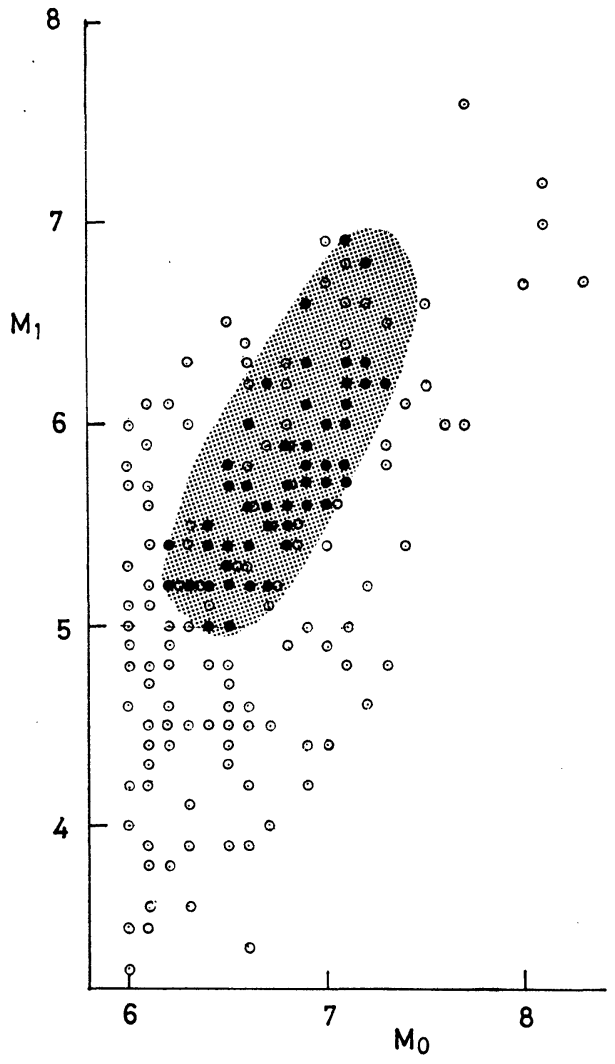

Fig. 3. The relation between magnitudes of the mainshock and the largest aftershock. Solid and open circles correspond to the simulated and the real aftershocks, respectively. 
向がよく一致していることである.このように本震の大きさが余震活動や最大余震の大きさに 関係するプロセスを具体的にさし示し，量的にそれを検討できる基盤を提供できるという意味 で，やはり浸透モデルは都合がいい。

\section{§5. 津波の波源域と余震域}

IIDA (1963)，羽鳥（1974）は津波の波源域と余震域 [宇津・関 (1955)，UTSU (1969)] が 一致することを述べている.

Fig. 4 は，この問題について筆者の考光 を模式的に示したものである，我が国に被害 を与える津波地震は, 一般に太平洋・フィリ ッピン海プレートのスラストにもとづく低角 断層の発生によるものと考えてよいであろ 5 .

今，断層面上に Fig. 4 の暗部で示したよ らなディスロケーションが起つたとする。そ の結果としての弾性反撥は，そのま上の海底 をゆり動かし，津波を発生する。つまり筆者

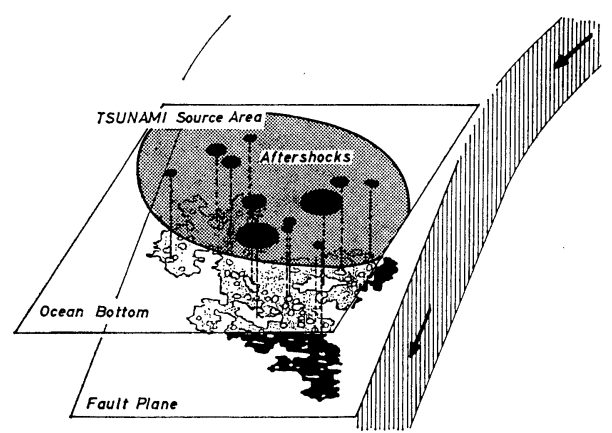

Fig. 4. Explanation of the coincidence of the area of Tsunami origin and of aftershock activity.

の考えでは，波源域とは断層面に出来た浸透模様の形のディスロケーションの海底への投影な のである. 一方，今迄述べてきたように浸透模様の中には，余震の“種”が用意されている. こう考えると，余震域が波源域と一致するといら筋書きは，浸透モデルの立場からはいわば当 然のことと解される.

\section{§6. 震度の領域と余震域}

村松 (1975) は，震度 VI の領域と余震域が一致することを見出している. 村松の説明通り, 震度 $\mathrm{V}$ を示すコンターの囲む領域は，あきらかに余震域にくらべて広すぎる，一体，震度の コンターの形と余震域の形の間に相関があることは想像できても，それが震度 V でなくVI である必然性はどこに求められるべきであろらか.

次に，この問題に触れてみたいと思らが，本題に入る前に震度 VI といら尺度がもつ意味を 考えてみよう.

今, Fig. 5 で暗部は限界一杯の歪をたくわえた領域であり，何かのきつかけでそのエネル ギーが，右の方へ弾性波として伝わつてゆく状況を示しているものとする．暗部の媒質には 
$(1 / 2) \mu x^{2}$ のエネルギーが単位体積当りたくわ えられている.ここに $\mu$ は剛性率, $x$ は限界 歪の大きさを示す. 今，このエネルギーが効 率 100\% で右方の媒質に伝わつて力学的工 ネルギーになつたとするとその運動エネルギ 一の極大值は単位体積当り $(1 / 2) \rho v^{2}$ となる 筈である.

ここに, $\rho$ は媒質の密度, $v$ はその粒子速 度の最大值である. 上の両者を等置して $v$ を求めると $v=\sqrt{\mu / \rho} \cdot x$ となる。 $\sqrt{\mu / \rho}$ は $\mathrm{S}$ 波速度であるから，仮りにこれを $4 \mathrm{~km} /$

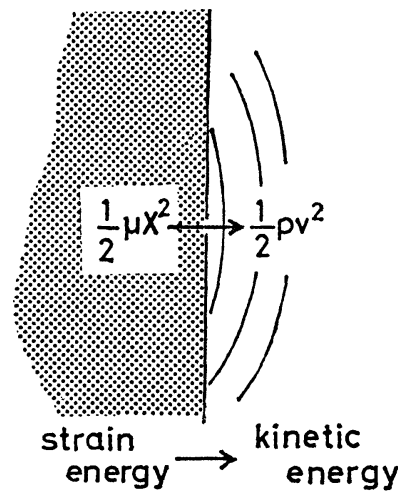

Fig. 5. Estimation of the maximum conceivable particle velocity of the medium in the proximity of the source domain.

sec とし， $x=10^{-4}$ としてみると $v=40(\mathrm{~cm} / \mathrm{sec})$ となる.つまり 40 kine の附近が，粒子速度 の限界值なのではないか。といらのが筆者の言いたいことである.

一方震度は，加速度と対応づけられてお拈，河角の式によると，震度 VI の下限は $250 \mathrm{gal}$ になる。これが 40 kine と対応づけられるのではないだろらか. 地震波のように非定常的な現 象に対して，定常的な見積りをしても，余り意味はないかも知れないが，一応 $|\alpha|=2 \pi f \cdot|v|$ といら式を使つて必要な 周波数を見積ると $f=1 \mathrm{c} / \mathrm{s}$ となり，余り非常識ではない值がえられ る. 大分荒つぽい見積りをしたが，数字の細かいことはここでは問題にしなくてよい，ただ， VI といら震度が，媒質の破壞する領域の近くのみで経験の近くされるものであることが言え ればそれでいいのである。

もら一つ, 大分地震のとき, 住民を対照にして表ら（1976）の抢こなつた意識調査の結果 は，上に述べた筆者の推測に照して，大変興味深い。彼等は，人々が地震に際して抱いた恐怖 感, 消火についての義務感などが震度の函数として著しく変ること, 震度 VI をこえると人々 は絶望的な恐怖感におそわれ，消火活動などは不可能な状態に陥ることを見出した。震度 V以 下と全く違つたことが起ることを思わせる。この結果を筆者は次のように解釈できないかと思 う．震度 VI で人が絶望的恐怖を覚えるのは，母なる大地がくづれることを直感したときの動 物としての本能に根ざすものではなかららか. この解釈は, やはり震度 VI といらものが媒質 の破壊領域のみで経験されるものであることをさし示している.

さて, ここで主題に戻ろう. 震度 VI の領域とは, 上の解釈からすと破壊域に近接した地 域にのみ起ることになる.Fig. 6 は内陸の地震につき, 震度 VI の領域と余域の一致を説明す る図である.内陸の地震にあつては, 一般に断層の傾きが大きいため, 震度 VI の領域が, 波 
源域における場合と少し違つた解釈が必要と なる他は筋書きは変らない。

\section{§7. 余震域の拡大}

茂木（1968）は大地震の余震域が時と共に 拡大してゆくことを述べている。これと同様 のことは観測精度の向上した今日では，小さ な地震の余震にも見られることがあきらかに されている. これを浸透モデルの立場から解 釈してみよう。

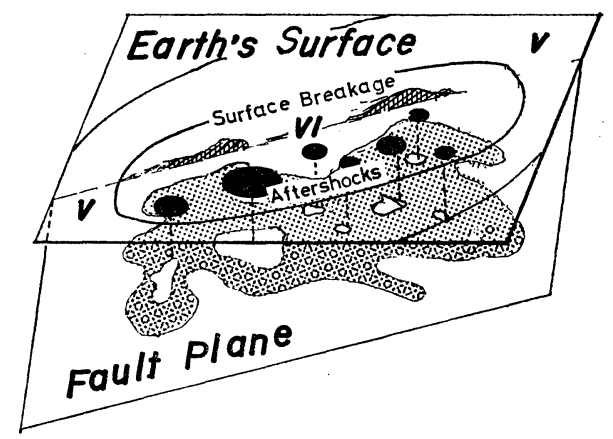

Fig. 6. Coincidence of the area of seismic intensity of VI and of aftershock activity.

これまでエネルギー解放部分に囲まれた未解放部分を一つ一つの余震に対応させて考元て来 たが，ここで Fig. 1 を見直すと完全に黒に包囲されてはいないがほとんぞ黒に囲まれている と言える部分があることに気付く，事柄が複雑になるので今迄はその部分は避けて，完全に黒 に包囲された空白域のみを余震の震源と考光たのであるが，こういら不完全に取り囲まれた部 分に何が起るかを考えてみよう，勿論，統計的にであるが，完全に包囲された部分と較べて， こうした部分が受けている応力は少ないであろう。その度合は包囲されている度合に依存し， 例えば三方向からとり囲まれているものは二方向のものよりも強い応力に曝されていると思つ てもよいであろう，応力のレベルの順位に応じて，空白域が余震になる時間が遅くなると考え よう。一方，浸透図形に拉いて，包囲の度合の少ないもの程，統計的に図形の外の方に位置す ると考えるのが自然である.

かくして，本震直後には完全に黒に包囲された空白部から先ず余震となり始め，次第に図形 の周辺部に存在する不完全な包囲部分の活動へと移つてゆく.これを余震の震源の位置といら 観点から眺めるとき，その活動域が拡大してゆくように見学るであろう。かくして，浸透図形 はしだいに，陥入部分の少ない形となり，最終的には外に対してほとんどが凸な形となつて余 震活動の終息を迎えるのではなかららか.

余震の時間的減衰については双曲線型の公式が当てはまることが知られている. この法則も 上のような筋書きで解釈できるのではないか，というのが筆者の考えでさるが，まだ具体的な 方向づけは見つかつていない。

\section{§ 8. Diffusion と Percolation}

筆者は，碁石モデルと浸透理論と題する論文の中で，“筆者にとつては捨てるにしのびない 
碁石モデルという名前は，浸透モデルといら．いささかいかめしい名前に書き改ためられねば ならなくなつた”と書いた，筆者は，地殼の中に存在する弱線が断層の成長を阻止することを 碁になぞらえて碁石モデルを提案したのであるが，“浸透モデル”といら名前をきいてみると いかにもその方がぴつたりするように思光て仕方がない。

勿論，浸透モデルといつても，必らずしも文字通り流体の浸透に適用されねばならないもの ではなく，筆者の如き発想にもそれなりの意味がある，しかし，ぞうも流体が直接震源過程に 効いているといら気がする，そこで当然思い浮かぶのは地震の発生に打ける水の重要性である (SCHOLTZ et al.; 1973). 筆者が断層のできる過程と思つていたのは，実は dilatant となつた 多孔質の地殼に水がしみ込んでゆく姿ではなかつたろらか。若しそらだつたら percolation model が適用されるのは寧ろ当然かも知れないのである.

ただし，厳密な用語の使い方によれば， diffusion は拡散であり，浸透 percolation とは区

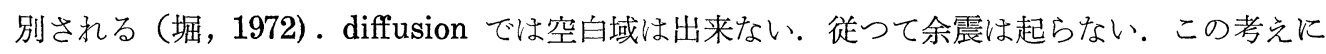
立つとすれば，余震の起るのは，水の運動が， percolation 的であるからということになる. 水が主破壞に先立ち percolation 的に dilatantな地殼に浸透し，領域が決まつた後に主破壞 が起るのかも知孔ない。

\section{§9. おわりに}

最後に，これまで筆者の述べて来た余震現象の観方に対してぴつたりあてはまる記述として 後藤（1962）の論文の一節を引用させていただく．後藤の論文は次のように述べている.

“余震の分布はしばしば非常に複雑であつて, あるものは枝分れして拉り, あるものは洞穴 状に欠けていて，そこには他の地震の余震が分布するといつた有様で，極端な場合には focal region は2つまたはそれ以上にちぎれている場合すらあるのではないか，とさ思觉る程で ある.”Fig. 1 の図形が示す複雑さと，多様性を考光併せると大変興味深いものがある.

\section{謝辞}

本研究の遂行に当つては京都大学防災研究所の三雲健博士からいただいた討論が有益であつ た. 深く感謝するものである.

また, 昭和 51 年の春季学会発表に際して, 東京大学地震研究所の羽鳥徳太郎博士, および 岐阜大学教育学部の村松郁栄博士から貴重なるスライドを择借した. ここに御礼を述べる. 


\section{文献}

後藤賢一，1962，余震分布と Magnitude との関係について，地震 2，15，116-121.

羽鳥徳太郎，1974，東北日本太平洋側に打る津波の波源，地震 2，27，321-337.

堀 素夫, 1972, 浸透理論とその応用, 日本統計学会誌, 3, 19-28.

IIDA, K., 1963, Magnitude of Tsunamigenetic Earthquake, Aftershock Area, and Area of Tsunami Origin, Geophys. Papers dedicated to prof. Kenzo Sassa, Geophys. Inst. Kyoto Univ., 115-124.

丸山卓男, 1975, 「碁石モデル」についての注意, 昭和 50 年度地震学会秋季大会講演予稿集, p 9. 茂木清夫, 1968 . 大地震の余震域の拡大，地震研究所彙報，46，175-203.

村松郁栄, 1975, 烈震域 (震度 VI) と余震域との関係, 昭和 50 年度地震学会秋季大会講演予稿集, p. 75 .

表俊一郎 - 甲斐直樹 - 三浪俊夫，強震度時の人間の心理・行動一大分県中部地震の場合一, 昭和 51 年 度地震学会春季大会講演予稿集 p. 68 .

大塚道男, 1971, 地震の起り方のシミュレーション，第二部 地震の規模別頻度分布，地震 2,24 , 215-227.

大塚道男, $1975 \mathrm{a}$ ，碁石モデルと浸透理論，地震 $2,28,96-97$.

大塚道男, $1975 \mathrm{~b}$, 碁石モデルは震源モデルとして不適当か, 昭和 50 年度地震学会秋季大会講演予稿 集, p. 10.

Scholtz, C. H., L. R. Sykes and Y.P. Aggarwal, 1973, Earthquake Prediction, A Physical Basis, Science, 181, 803-809. 